\title{
EFFECT OF SLABS IN SPACE FRAMED STRUCTURES UNDER SEISMIC LOADING
}

\author{
F.K Abdel Sayed ${ }^{1}$, Ahmed. Abdel Reheem Farghly ${ }^{2}$, \\ Shehata. E. Abdel Reheem ${ }^{3}$, Ashraf A. Mohamed ${ }^{4}$ and M. N. Mohamed ${ }^{5, "}$ \\ 1,3,4 Staff in Civil Eng. Dep., Faculty of Engineering, Assiut University, Assiut, Egypt \\ ${ }^{2}$ Civil and Architectural Constructions Department Industrial Education College, Sohag \\ University, Sohag, Egypt \\ ${ }^{5}$ Technical Marketing Manager, CEMEX Company
}

Received 2 October 2013; accepted 21 October 2013

\begin{abstract}
Frame system structures which composed of only reinforced concrete columns, beams and slabs, have been widely adopted for many framed buildings. Generally, in-plane stiffness of slabs is ignored in the conventional analysis of such structures. However, in reality, the floor slabs may have some influence on the lateral response of the structures. Consequently, if the in-plane stiffness of slabs in a frame system structure is totally ignored, the lateral stiffness of the global frames may be underestimated. Therefore, the objective of the research is to investigate the effect of floor diaphragms in multi-story frames by comparing frames models with different slabs thickness by those without slabs. Furthermore, it can be seen from the study that the slab thickness is an important factor increasing in-plane stiffness of the slab and consequently increasing the overall inplan stiffness of the building leading to an increase in base shear and a decrease in lateral displacements values.
\end{abstract}

Keywords: rigid floor diaphragm, flexible floor diaphragms, in-plan deformation, floor diaphragm action and time history analysis

\section{Introduction}

Floor diaphragms in-plane stiffness affects building response to seismic ground accelerations; it is generally provided primarily to resist out-of-plane vertical gravity loads in the structure. However, for reliable performance, there diaphragms must resist lateral forces (such as earthquake) and transfer them dependably to the vertical lateral force resisting elements (such as walls and frames) within a structure [7].

Under Seismic loading, floor systems in reinforced concrete (RC) buildings act as diaphragm to transferee lateral earthquake loads to the vertical lateral force-resisting system [3].

Floor in-plane stiffness plays an important role in distributing seismic forces to lateralresisting elements. In most cases, the assumption of rigid floor allows a significant reduction of computational effort in the structural analysis of buildings. In some cases, however, structural configurations with large spans between lateral resisting elements can invalidate the use of the rigid-floor assumption. For these cases, diaphragm flexibility must be considered in the analysis. Moreover, in the case of plans with irregular distributions of mass or stiffness, torsional unbalance can exacerbate the effects of floor flexibility [2]. Additionally, when the structure stiffness increases it can absorb greater lateral forces induced by the earthquake motions [8].

\footnotetext{
* Corresponding author.

E-mail address: mnace2003@ hotmail.com
} 
M. N. Mohamed et al., Effect of slabs in space framed structures under seismic loading, pp. 2065 - 2078

To study the effect of diaphragm action of floor slabs on building response, first, this paper discusses in-plan characteristics of R.C. floor slabs, the most critical factor to control the diaphragm action, on the basis of the results of previously conducted experiments [4], [5].

So, in order to predict accurate lateral displacements and base shear values of a frame system structures, it may be prudent to include in-plane stiffness of slabs.

"The problem statement of this research is to find out the relationship between lateral stiffness and both base shear values and lateral deflection of frames based on in-plane stiffness of slabs".

\section{Aims and Objectives}

Numerical methods have been widely used in solving engineering non-linear problems. Therefore, the main objectives of this study are: -

- To monitor and analyze the effect and the contribution of the below parameters on both base shear values and lateral displacements of high-rise building under seismic loading:

1 - The effect of slabs (slab thickness or diaphragm effect).

2 -Rectangularity ratio of the building plan.

\section{Model Description}

The study will conduct non-linear finite element analysis using SAP2000 program for the frame.

Figure 1 shows the structural plan of the used model, a 30 story building, with identical plan (as shown in figure 1) have been considered in the analysis. The overall plan dimensions are $6.0 \mathrm{~m} \times 6.0 \mathrm{~m}$ for each bay $(2 \times 2$ bay, $2 \times 4$ bays and $2 \times 6$ bays with three corresponding rectangularity ratios, length / width ratio $=1:-1: 2-1: 3$ respectively), measured from the centre line of the columns. The height of the ground floor is $3.0 \mathrm{~m}$ and inters stories heights are $3 \mathrm{~m}$. The thickness of the analyzed slab models has been considered as: no existing slabs, $8 \mathrm{~cm}, 10 \mathrm{~cm}$ and $12 \mathrm{~cm}$. Columns are with size at ground and first floors with $70 \times 70 \mathrm{~cm}$ dimension and $24 \varnothing 16 \mathrm{~mm}$, and dimensions of columns reduced by $5 \mathrm{~cm}$ in both directions every 2 floors until reaching columns size $40 \times 40 \mathrm{~cm}$, $6 \varnothing 8 / \mathrm{m}$ ' stirrups reinforcement, and beams with constant size $25 \times 50 \mathrm{~cm}$ and $4 \varnothing 16 \mathrm{~mm}$ bottom and upper reinforcement, $7 \varnothing 8 \mathrm{~mm} / \mathrm{m}$ ' stirrups reinforcement.

\subsection{Input loadings}

A time history analysis was carried out using El Centro earthquake which has maximum acceleration $0.5 \mathrm{~g}$ (figure 2) the earthquake affects on $\mathrm{Y}$ directions of the tested model.

Journal of Engineering Sciences, Assiut University, Faculty of Engineering, Vol. 41, No. 6, November, 2013, E-mail address: jes@aun.edu.eg 


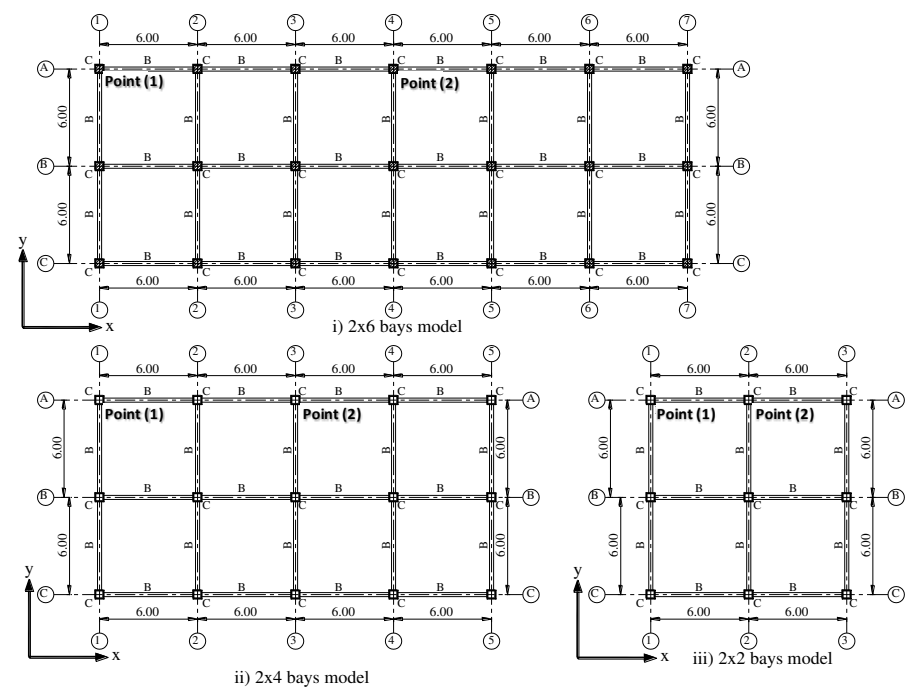

Fig. 1. Structural plan of the tested models

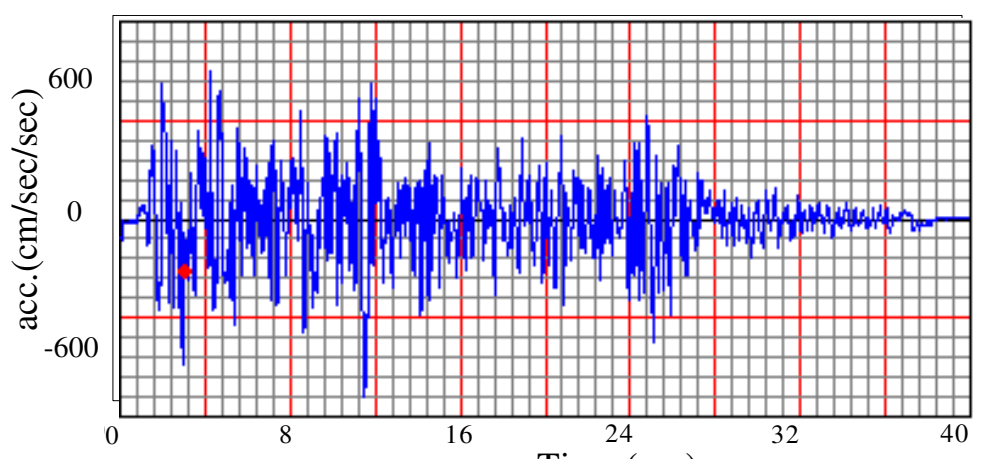

Fig. 2. El Centrio Model (sequration

\section{Results and Discussion}

Three models were undertaken, three different rectangularity ratios (length / width ratio $=1:-1: 2-1: 3$ ) to discuss the effects of slab diaphragm on the 3D frame seismic analysis. The effects of slabs thickness or absence was measured by the values of displacement of some selected points (point (1) and point (2) as shown in figure 1) and compare its displacements values in direction perpendicular on the length of the tested models to show after that the effects of slab diaphragm on base shear.

\section{First: Study the effect on lateral displacements values:}

In this part, in purpose to show the in-plan deformation and the effect of diaphragm on the lateral distortion of the floor plan, three main analyzed cases will be discussed as follows:

Journal of Engineering Sciences, Assiut University, Faculty of Engineering, Vol. 41, No. 6, November, 2013, E-mail address: jes@aun.edu.eg 


\section{The first case}

Figures (3-i, 3-ii, 3-iii and 3-iv) represent the displacements in y direction for the selected points (1), (2) in case of 30 story building, $2 \times 6$ bay (rectangularity ratio $=1: 3$ as shown in figure 1-i) and various slab cases (No slab, $8 \mathrm{~cm}, 10 \mathrm{~cm}$ and $12 \mathrm{~cm}$ ).

Figure (3-i) shows the comparison between displacement in y direction for points (1) and (2) in case of no slab, at floors (from 9 to 30 stories) there is a clear difference between the two selected points in average $21.7 \%$ against $5.5 \%$ in the first nine floors, this means that these points are deformed each one alone. figure (3-ii) using $8 \mathrm{~cm}$ slab (diaphragm) shows a less diversion between the two values of displacements in y direction for all floors except a slightly difference between the two points displacements in the last floors in average $=1.4$ $\%$. And for figure (3-iii) using a $10 \mathrm{~cm}$ slab less diversion occurred, while in figure (3-iv) with using $12 \mathrm{~cm}$ slab thickness, the difference between lateral displacement (Uy) of points (2) and (1) = zero all over the building (rigid floor diaphragm effect).

- So it can be stated that:

1. By increasing slab thickness the difference between points (1) and (2) displacements are reduced, reaching zero in high stiffness slab such as in case of $12 \mathrm{~cm}$. (means that by increasing slab thickness, the slab acts as a rigid diaphragm).

2. Increasing slab thickness (stiffness) reduces the average lateral displacements values. This inverse relation is demonstrated in the below two examples:

2-1 The average displacements were $24.7,17.41,16.8 \& 15.1$ in the four scenarios of slabs thickness (no slab, $8,10,12 \mathrm{~cm}$ ) respectively.

2-2 By monitoring the reduction in displacements of each point (1) and (2)

separately, when increasing slab thickness from zero thickness (no slab) to $12 \mathrm{~cm}$, the below reductions percentages in the point's displacements were occurred:

○ $31 \%$ for point (1) and $35.6 \%$ for point (2) in the first floor.

○ $24.9 \%$ for point (1) and $41.3 \%$ for point (2) in the last floor.

3- The maximum displacement occurred in the four cases in the last floor while the minimum displacement occurred in the first floor, it was also noticed in no slab case that after the eighth floor approximately the diversion started to be more significant and the higher story have bigger difference between the displacements of the two points $(1,2)$.

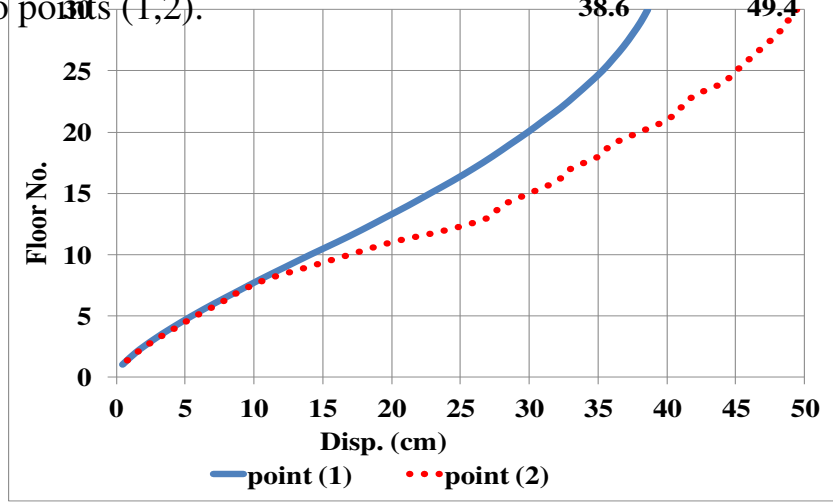

Fig 3. i. Comparison between lateral displacements of points (1) and (2) in 30 story building, $2 \times 6$ bay and no slab model

Journal of Engineering Sciences, Assiut University, Faculty of Engineering, Vol. 41, No. 6, November, 2013, E-mail address: jes@aun.edu.eg 


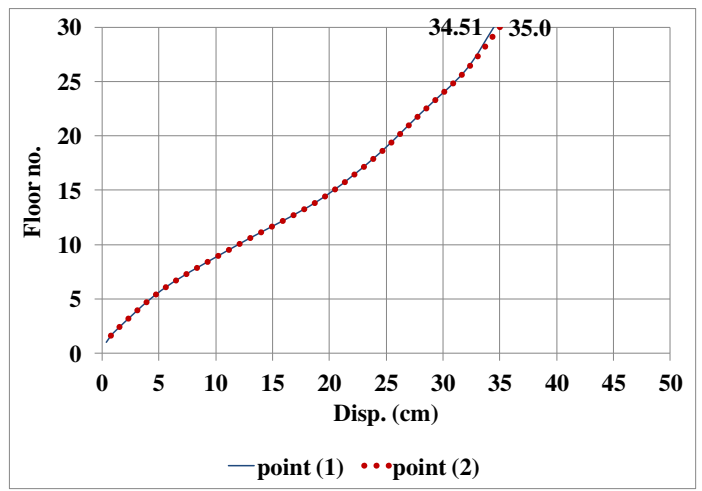

Fig. 3. ii. Comparison between lateral displacements of points (1) and (2) in 30 story building, $2 \times 6$ bay, $8 \mathrm{~cm}$ slab model

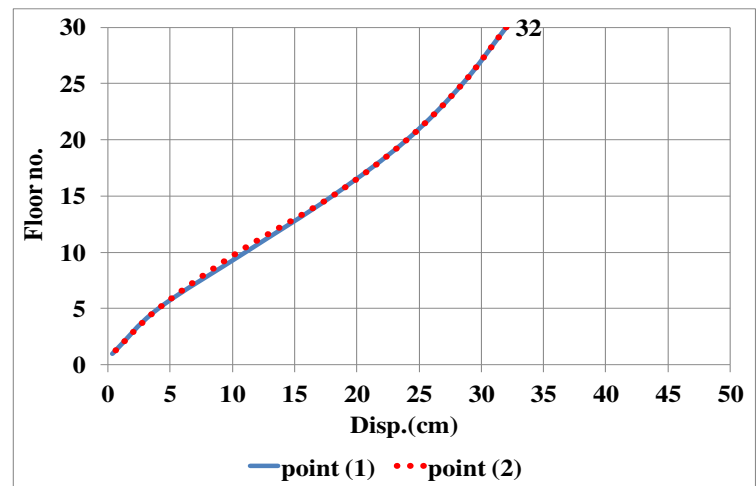

Fig. 3. iii. Comparison between lateral displacements of points (1) and (2) in 30 story building, $2 \times 6$ bay, $10 \mathrm{~cm}$ slab model

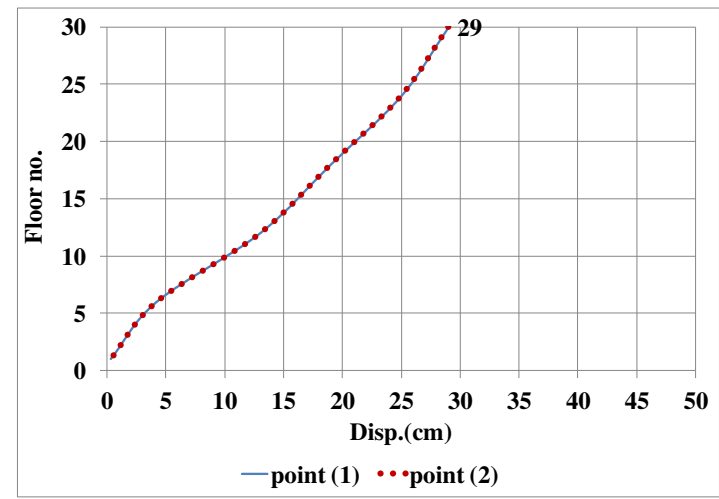

Fig. 3. iv. Comparison between lateral displacements of points (1) and (2) in 30 story building, $2 \times 6$ bay, $12 \mathrm{~cm}$ slab model

Journal of Engineering Sciences, Assiut University, Faculty of Engineering, Vol. 41, No. 6, November, 2013, E-mail address: jes@aun.edu.eg 


\section{The second case}

Figures (4-i, 4-ii, 4-iii and 4-iv) represent the displacements in y direction for the selected points (1), (2) in case of 30 story building, $2 \times 4$ bay (rectangularity ratio $=1: 2$ as shown in figure 1-ii) and various slab cases (No slab, $8 \mathrm{~cm}, 10 \mathrm{~cm}$ and $12 \mathrm{~cm}$ ).

Figure (4-i) shows the comparison between displacement in y direction for points (1) and (2) in case of no slab, there are clear differences between the two selected points in average equal $11.7 \%$, this means that these points in general are deformed each one alone. On the other hand from figures (4-ii), (4-iii) and (4-iv) using $8 \mathrm{~cm}, 10 \mathrm{~cm} \& 12 \mathrm{~cm}$ slab (diaphragm) respectively, it is so clear that the difference between lateral displacement (Uy) of points (2) and (1) equal zero all over the building, (means that, the slab worked as a rigid diaphragm.

- So it can be stated that:

1. By increasing slab thickness the difference between points (1) and (2) displacements are reduced, reaching zero in high stiffness slab (as in slabs thickness 8, 10 and 12 cm cases), means that by increasing slab thickness, the slab acts as a rigid diaphragm.

2. Increasing slab thickness (stiffness) reduces the average lateral displacements values. This inverse relation is demonstrated in the below two examples:

2-1 The average displacements were $18.6,14.7,13.3 \& 12$ in the four scenarios of no slab, $8,10,12 \mathrm{~cm}$ slab thickness respectively (means that by increasing slab thickness the displacements were reduced).

2-2 By monitoring the reduction in displacements of each point (1) and (2) separately, when increasing slab thickness from zero thickness (no slab) to $12 \mathrm{~cm}$, the below reductions percentages in the point's displacements were occurred:

- $7.5 \%$ for point (1) and $21.3 \%$ for point (2) in the first floor

- $33 \%$ for point (1) and 39\% for point (2) in the last floor

3. The maximum displacement occurred in the four cases in the last floor while the minimum displacement occurred in the first floor, it was also noticed in no slab case that the higher story have bigger difference between the displacements of the two points $(1,2)$.

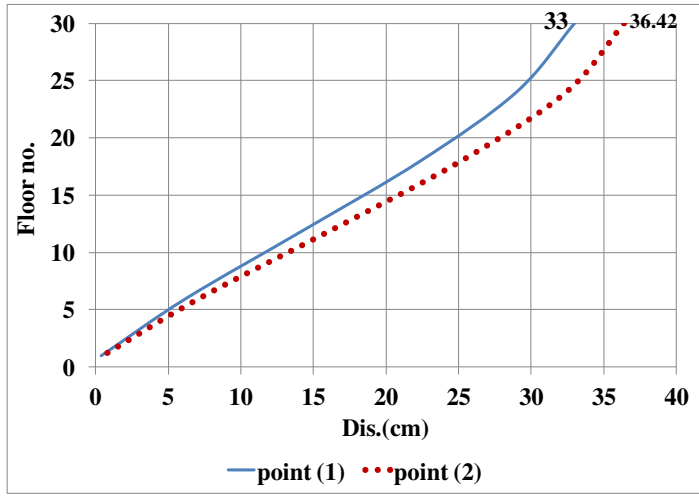

Fig. 4. i. Comparison between lateral displacements of points (1) and (2) in 30 story building, $2 \times 4$ bay and no slab model

Journal of Engineering Sciences, Assiut University, Faculty of Engineering, Vol. 41, No. 6, November, 2013, E-mail address: jes@aun.edu.eg 


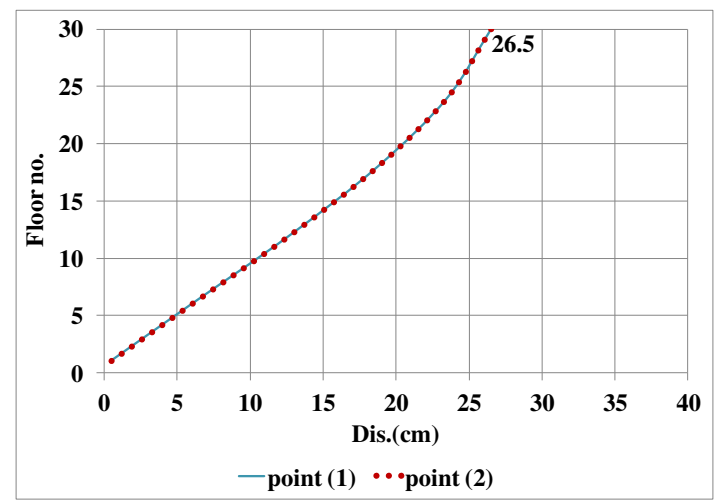

Fig. 4. ii. Comparison between lateral displacements of points (1) and (2) in 30 story building, $2 \times 4$ bay, $8 \mathrm{~cm}$ slab model

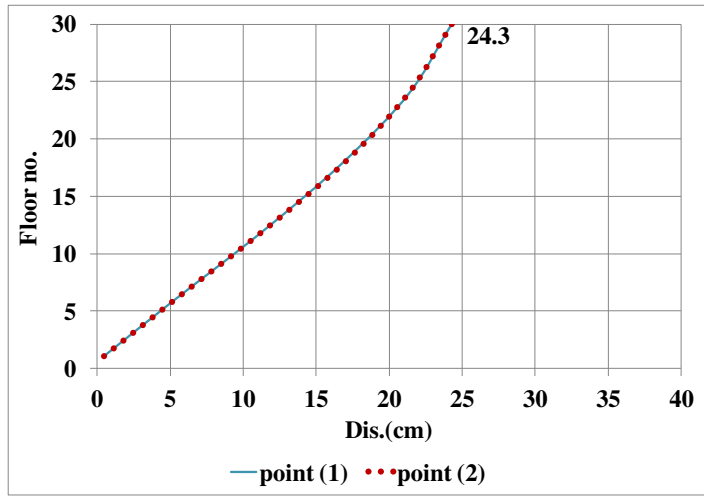

Fig. 4. iii. Comparison between lateral displacements of points (1) and (2) in 30 story building, $2 \times 4$ bay, $10 \mathrm{~cm}$ slab model

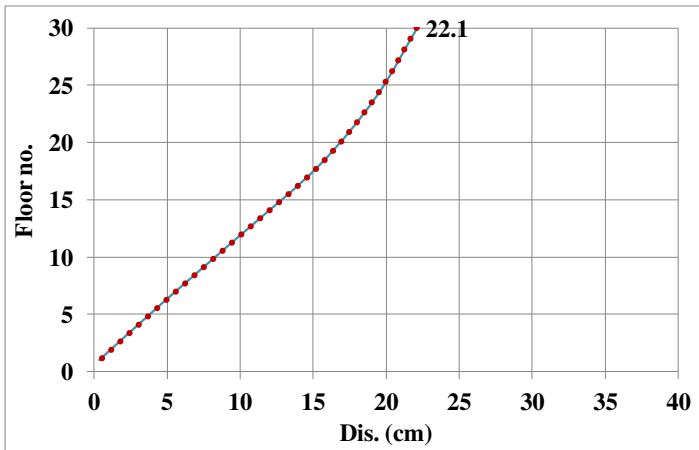

一point (1) $\cdots$ point (2)

Fig. 4. iv. Comparison between lateral displacements of points (1) and (2) in 30 story building, $2 \times 4$ bay, $10 \mathrm{~cm}$ slab model

Journal of Engineering Sciences, Assiut University, Faculty of Engineering, Vol. 41, No. 6, November, 2013, E-mail address: jes@aun.edu.eg 


\section{The Third Case}

Figures (5-i, 5-ii, 5-iii and 5-iv) represent the displacements in y direction for the selected points (1), (2) in case of 30 story building, $2 \times 2$ bay (rectangularity ratio $=1: 1$ as shown in figure 1-ii) and various slab cases (No slab, $8 \mathrm{~cm}, 10 \mathrm{~cm}$ and $12 \mathrm{~cm}$ ).

From figures (5-i, 5-ii, 5-iii and 5-iv) it can be observed that, although the reduction of maximum displacement by increasing slab thickness, there are a difference between the lateral displacements in all cases between the two points. Also it is the only case between the three cases that point (1) displacements values are more than point (2)

- So it can be stated that:

1.By increasing slab thickness the difference between points (1) and (2) displacements are reduced, (Average differences $=40 / \%$ in case of no slab, and equal $=38.5 \%$ in the three other cases when slab thickness $=8 \mathrm{~cm}, 10 \mathrm{~cm}, 12 \mathrm{~cm}$ ) (flexible floor diaphragms effect).

2. There is inverse relationship between slab thickness and points lateral displacements for example:

2-1 The average displacements were $16.7,14.6,13.0 \& 12.1$ in the four scenarios of no slab, 8, 10, $12 \mathrm{~cm}$ slab thickness respectively.

2-2 By monitoring the reduction in displacements of each point (1) and (2)

separately, when increasing slab thickness from zero thickness (no slab) to $12 \mathrm{~cm}$, the below reductions percentages in the point's displacements were occurred:

$\circ \quad$ In the first floor, by $26.2 \%$ for point (1) and $17.6 \%$ for point (2).

○ In the last floor, by $26.3 \%$ for point (1) and $26.1 \%$ for point (2).

3. The maximum displacement occurred in the four cases in the last floor while the minimum displacement occurred in the first floor, it was also noticed in no slab case that the higher story have bigger difference between the displacements of the two points $(1,2)$.

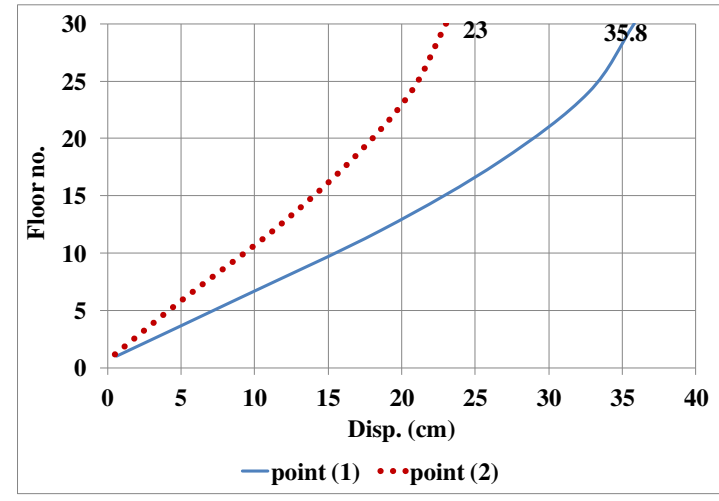

Fig. 5. i. Comparison between lateral displacements of points (1) and (2) in 30 story building, $2 \times 2$ bay and no slab model

Journal of Engineering Sciences, Assiut University, Faculty of Engineering, Vol. 41, No. 6, November, 2013, E-mail address: jes@aun.edu.eg 


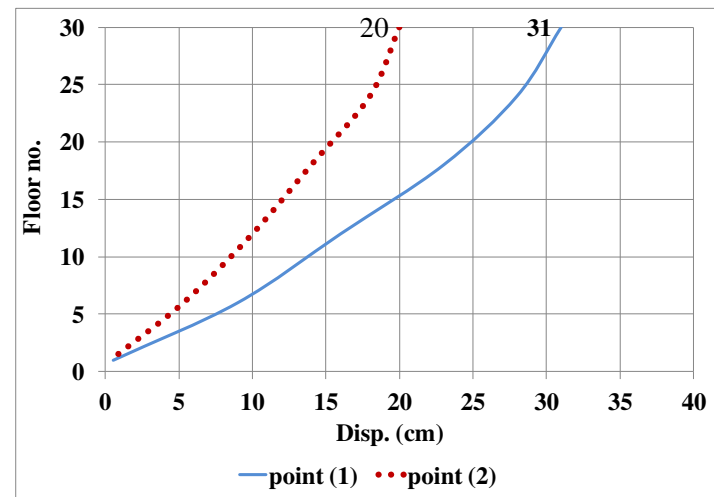

Fig. 5. ii. Comparison between lateral displacements of points (1) and (2) in 30 story building, $2 \times 2$ bay, $8 \mathrm{~cm}$ slab model

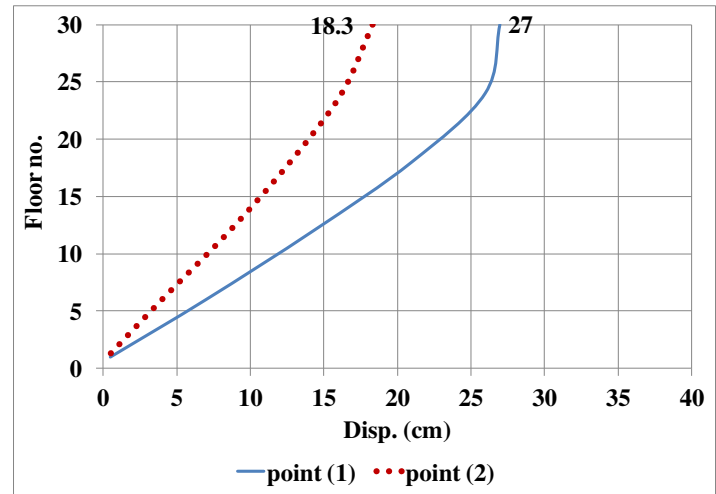

Fig. 5. iii. Comparison between lateral displacements of points (1) and (2) in 30 story building, $2 \times 2$ bay, $10 \mathrm{~cm}$ slab model

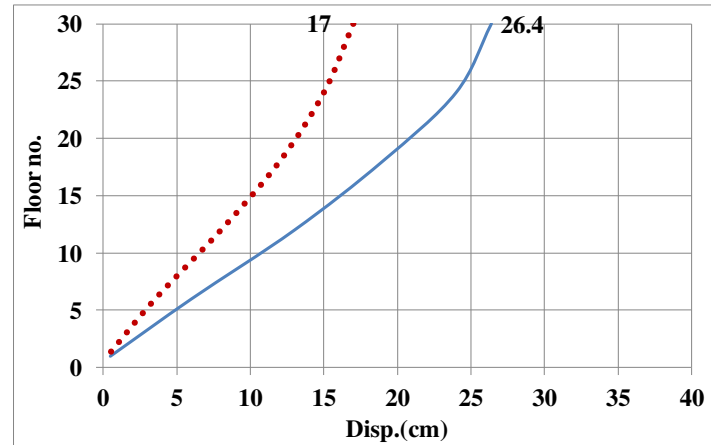

一point (1) - - point (2)

Fig. 5. iv. Comparison between lateral displacements of points (1) and (2) in 30 story building, $2 \times 2$ bay, $12 \mathrm{~cm}$ slab model

Journal of Engineering Sciences, Assiut University, Faculty of Engineering, Vol. 41, No. 6, November, 2013, E-mail address: jes@aun.edu.eg 


\section{The effect of rectangularity ratio on lateral displacements values:}

From the above three cases, the below findings were observed

- When comparing the effect of the slab thickness (diaphragm effect) in the three rectangularity ratio cases $(1: 1,1: 2,1: 3)$, it can be stated that, slab thickness has a strong influence on reducing the average lateral displacements and this influence are increased by increasing rectangularity ratio, as illustrated by the below example and shown in table (1):

- In the first case: when rectangularity ratio=1:3, increasing slab thickness from no slab scenario to $12 \mathrm{~cm}$ thickness leads to decrease the average lateral displacements by $38.9 \%$

- In the second case: when rectangularity ratio=1:2, increasing slab thickness from no slab scenario to $12 \mathrm{~cm}$ thickness leads to decrease the average lateral displacements by $34.9 \%$

- In the third case: when rectangularity ratio=1:1, increasing slab thickness from no slab scenario to $12 \mathrm{~cm}$ thickness leads to decrease the average lateral displacements by $28.1 \%$

From the above it is clear that by increasing the rectangularity ratio the reduction occurred to the lateral displacement when increasing slab thickness become more significant.

\section{Table 1.}

indicates the average displacements $(\mathrm{cm})$ of the two point $(1,2)$ for 30 story building

\begin{tabular}{|c|c|c|c|c|c|}
\hline \multirow{5}{*}{$\begin{array}{c}\text { Average. } \\
\text { displacements } \\
(\mathrm{cm})\end{array}$} & \multirow{2}{*}{$\begin{array}{c}\text { Rectangularity } \\
\text { Ratio }\end{array}$} & \multirow{2}{*}{$\begin{array}{c}\text { No slab } \\
\text { case }\end{array}$} & \multicolumn{3}{|c|}{ Slab thickness $(\mathrm{cm})$} \\
\hline & & & $8 \mathrm{~cm}$ & $10 \mathrm{~cm}$ & $12 \mathrm{~cm}$ \\
\hline & 1:3 (2x6 bay) & 24.7 & 17.4 & 16.8 & 15.1 \\
\hline & 1:2 (2x4 bay) & 18.6 & 14.7 & 13.3 & 12.1 \\
\hline & 1:1 (2x2 bay) & 16.7 & 14.6 & 13 & 12.0 \\
\hline
\end{tabular}

It is worthy to mention that in no slab case, the lateral displacements of point (1) are less than the lateral displacements of point (2), this is occurred in two cases of rectangularity ratio (1:3 and 1:2), while in case of rectangularity ratio $1: 1$ the lateral displacements of point (1) are more than the lateral displacements of point (2).

\section{Second: Study the effect on base shear values:}

Figure 6 indicates the differences between the values of base shear for the three models with fixed stories no $=30$ story and different rectangularity ratio $(1: 1,1: 2$ and 1:3) with various slab thickness.

From figure 6, the below relationships can be estimated:

1 - There is direct relationship between base shear value and slab thickness, this relationship is indicated in the below percentages:

- In case of rectangularity ratio $=1: 3$, the increasing percentage in base shear value $=$

$211 \%$ when increasing slab thickness from no slab case to $12 \mathrm{~cm}$ thickness.

○ In case of rectangularity ratio $=1: 2$, the increasing percentage in base shear value $=$ $317 \%$ when increasing slab thickness from no slab case to $12 \mathrm{~cm}$ thickness.

- In case of rectangularity ratio $=1: 1$, the increasing percentage in base shear value $=$ $375 \%$ when increasing slab thickness from no slab case to $12 \mathrm{~cm}$ thickness.

Journal of Engineering Sciences, Assiut University, Faculty of Engineering, Vol. 41, No. 6, November, 2013, E-mail address: jes@aun.edu.eg 
M. N. Mohamed et al., Effect of slabs in space framed structures under seismic loading, pp. 2065 - 2078

From the above percentages, it is obviously obtained that when increasing slab thickness and decreasing the rectangularity ratio the influence of slabs thickness in increasing base shear value become more effective and clear.

2 - There is direct relationship between base shear value and rectangularity ratio.

- The base shear value increased in average by $54 \%$ when increasing rectangularity ratio from 1:1 ( $2 \times 2$ bays) to 1:2 (2x4) case.

- The base shear value increased in average by $27 \%$ when increasing rectangularity ratio from 1:2 (2x4 bays) to 1:3 (2x6) case.

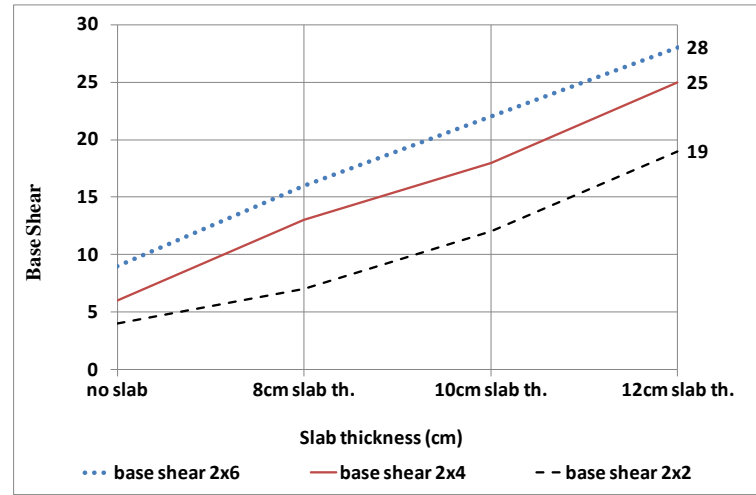

Fig. 6. Comparison between base shear values in 30story building with various rectangularity ratios $1: 1, \quad 1: 2$ and $1: 3 \quad(2 \times 2,2 \times 4$ and $2 \times 6$ bays) models with different slab thickness

\section{Conclusions}

According to the results obtained from the studied cases it can be stated that slab inplane stiffness (Diaphragm) has significant influence in the response of high-rise building under seismic loading, this influence can be concluded as follows:

\section{Influence on the lateral displacements:}

- Increasing slab thickness under seismic loading, works on reducing the overall average lateral displacements of the building.

- Additionally, the thickness of the slab (diaphragm effect) has a strong influence on reducing the differential lateral displacements hence avoiding as possible any probable distortion.

And so, it can be concluded that, in this study there is an inverse relationship between slab in-plane stiffness (thicknesses) with both lateral displacements and differential lateral displacements.

- Slab in-plan stiffness has a clear influence on reducing the average lateral displacements and this influence increases by increasing rectangularity ratio as follows:

- The average decreasing percentage that occurred to lateral displacements due to increasing slab thickness from zero slab to $8 \mathrm{~cm}$ to $10 \mathrm{~cm}$ to $12 \mathrm{~cm}$, for the three rectangularity ratios $1: 1,1: 2$ and $1: 3$ are $31.2 \%, 39.5 \%$ and $43.1 \%$ respectively.

Journal of Engineering Sciences, Assiut University, Faculty of Engineering, Vol. 41, No. 6, November, 2013, E-mail address: jes@aun.edu.eg 
- Increasing rectangularity ratio leads to increase lateral displacements values, The corresponding average displacements values for 30 story building with slab thickness $=10 \mathrm{~cm}$ were $16.8,13.3$ and $13.0 \mathrm{~cm}$ for rectangularity ratios $=1: 3,1: 2$ and $1: 1$ respectively.

- There is direct relationship between number of stories and both lateral displacements values and the differential lateral displacements.

\section{Influence on the base shear values:}

Also the present study introduced an analysis concerning the effect of slab thickness (lateral stiffness) and rectangularity ratio on the value of base shear under seismic loading, and from this study the below relationships can be stated as follows:

- There is direct relationship between base shear value and slab thickness, in addition to that it is obviously obtained that when increasing slab thickness and decreasing the rectangularity ratio the influence in increasing base shear value become more significant as follows:

- By increasing slab thickness from zero slab case to $12 \mathrm{~cm}$ thickness in 30 story building the percentage increasing in base shear values were: $211 \%, 315 \%$ and $375 \%$ for rectangularity ratios 1:3,1:2 and 1:1 respectively.

- There is direct relationship between base shear value and rectangularity ratio. The base shear value increased in average by $40.5 \%$ when increasing rectangularity ratio in the two following cases: from 1:1 ( $2 \times 2$ bays) to 1:2 ( $2 \times 4$ bay) and from 1:2 (2x4 bays) to 1:3 (2x6 bay).

Finally, based on the above results, this research proved that the slab in-plane stiffness (floor diaphragm action) plays clear and important role in decreasing the overall lateral displacement of the high-rise building under seismic loading, also it works on reducing differential lateral displacements. Furthermore increasing building rectangularity leads to increasing the effectiveness of slabs for decreasing lateral displacements values.

- Also through the presented study, it was proved that there are direct relationships between base shear value and both of slab thickness and rectangularity ratio.

- So, it can be seen from the study that the slab actually is acting important role to increase the overall in-plan stiffness of the models leading to increase the base shear and reduce both lateral displacements and in-plan deformation (lateral distortion).

However, the Egyptian code (201/2008) neglects the effect of slab in-plane stiffness (thickness) in calculating both base shear values and lateral displacements, leading to high displacements values and low base shear far from the actual behavior resulting in an inaccurate design.

Therefore, this study strongly recommends that such important parameter, Diaphragm effect (slab thickness) should be taken into account in computing base shear value and lateral displacements in multi-story building under seismic loading.

\section{References}

[1] Egyptian Code (201) for calculating Loads and forces for Construction Works, Research Center for Housing and Construction, Ministry of Housing, Utilities and Urban Planning, Cairo, Egypt, 2008.

Journal of Engineering Sciences, Assiut University, Faculty of Engineering, Vol. 41, No. 6, November, 2013, E-mail address: jes@aun.edu.eg 
M. N. Mohamed et al., Effect of slabs in space framed structures under seismic loading, pp. 2065 - 2078

[2] Jaime De La Colina: Effect of floor in plane flexibility on the response of torsionally unbalanced systems, 2000.

[3] Joel M.Barron and Mary Beth D. Hueste, Diaphragm Effects in Rectangular Reinforced Concrete Buildings, ACI Structural Journal / September - October 2004

[4] Karadogan, H. F. et al., "Behavior of flat plate floor systems under in-plan seismic loading", Proceedings, 7WCEE, Vol. 5, Turkey, pp. 9-16.

[5] Nakashima, M., Hung, T., and Lu, L. W., "Experimental study of beam-supported slabs under in-plan loading", ACI Journal, Vol. 79 No. 1 Jan/Feb 1982, pp. 59-65.

[6] SAP2000 Analysis Reference, Volume 1, Computers and Structures, Inc.,Berkeley, CA, 1997.

[7] Vinod K. Sadashiva1, Gregory A. MacRae1, Bruce L. Deam1 and Matthew S. Spooner: Quantifying the seismic response of structures with flexible diaphragms, New Zealand, Copyright (C) 2012 John Wiley \& Sons, Ltd.

[8] Wai-Fah Chen : Earthquake Engineering Handbook, Hawaii University, Charles Scawthorn, 2003.

\section{تأثير البلاطات فى منشآت الأطر الفراغية تحت تأثثر الحمل الزلزالي}

\section{الملخص العربي}

تهذف هذه الدر اسة للتحقق من نأثير سمك البلاطة (الدايافر ام) على السلوك الإنشـائي للمباني عاليـه الارتفاع

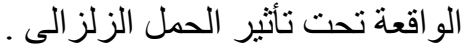

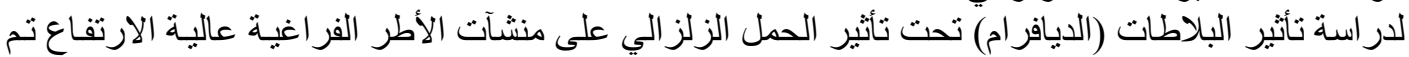

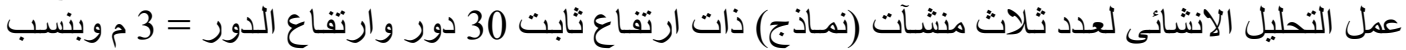

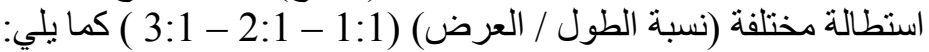

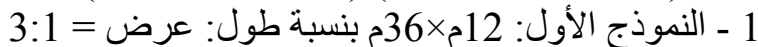

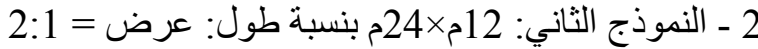

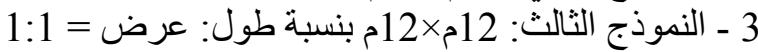

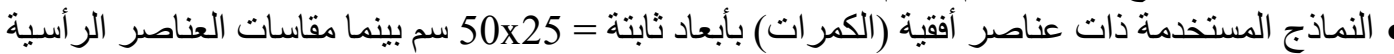

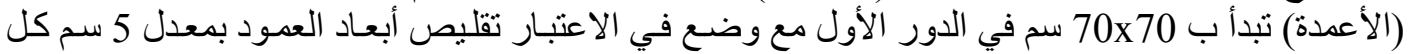

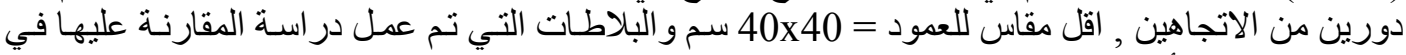

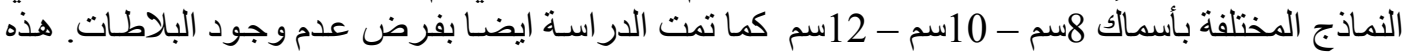

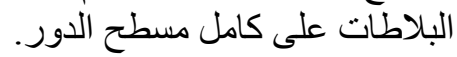

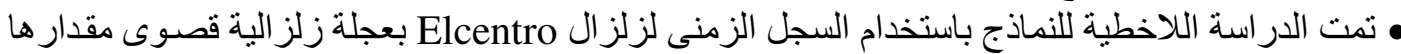

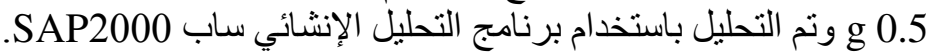

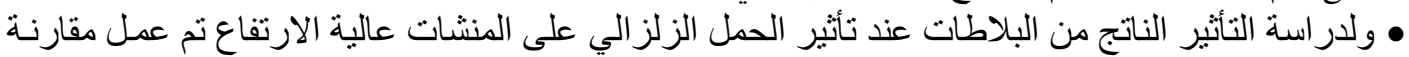

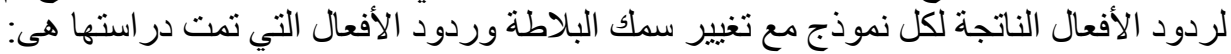

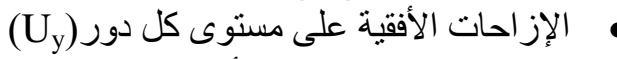

$$
\begin{aligned}
& \text { قوى القص القاعدي للمنشأ ككل. }
\end{aligned}
$$

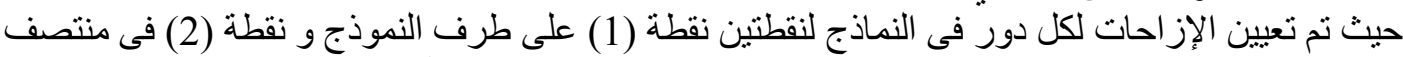

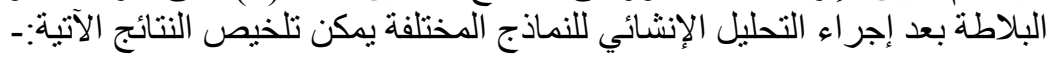

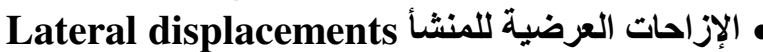

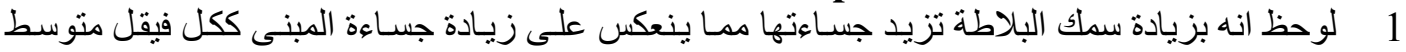

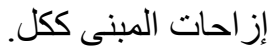

Journal of Engineering Sciences, Assiut University, Faculty of Engineering, Vol. 41, No. 6, November, 2013, E-mail address: jes@aun.edu.eg 
M. N. Mohamed et al., Effect of slabs in space framed structures under seismic loading, pp. 2065 - 2078

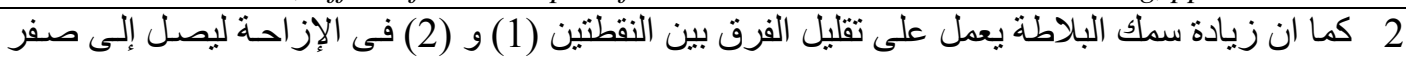

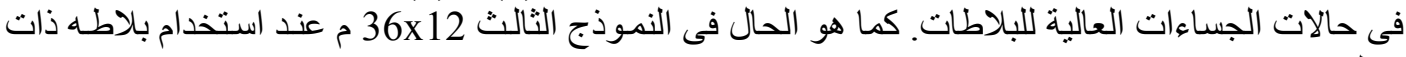
سمك = 12سم. هذا ويمكن القول انه هناك علاقة عكسية بين سمك البلاطة وكلاً من الاز احه العرضية للمبنى ككل و الفرق فى الإزاحات بين النقاط.

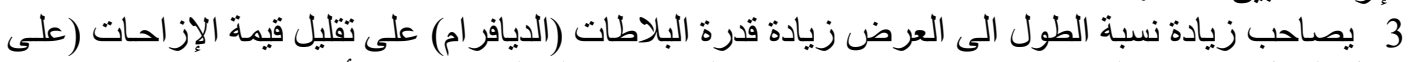

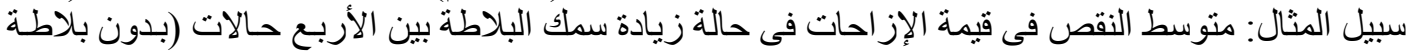

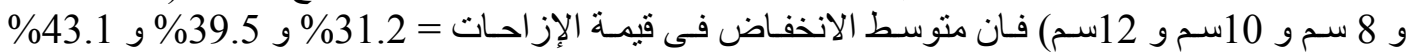

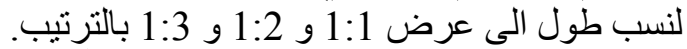

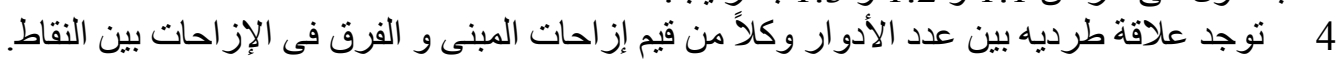

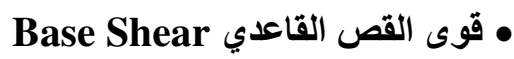
5 6

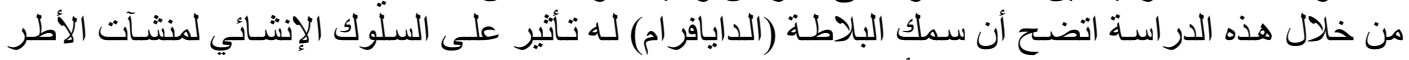

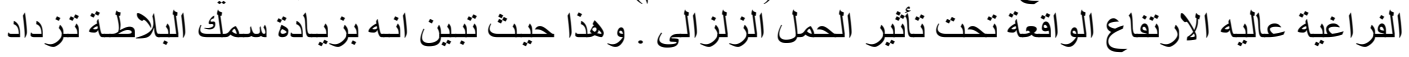

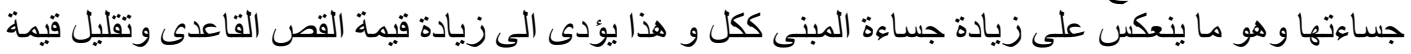

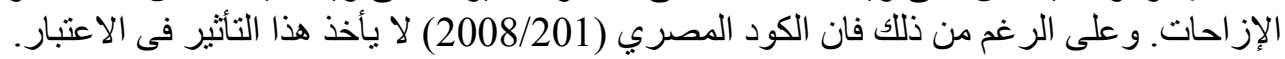

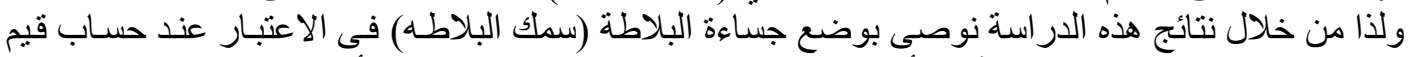

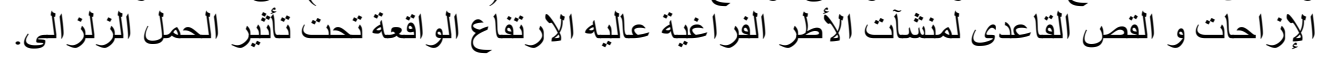

Journal of Engineering Sciences, Assiut University, Faculty of Engineering, Vol. 41, No. 6, November, 2013,E-mail address: jes@aun.edu.eg 